\title{
IMPROVEMENT OF SKIN HYDRATION PERCENTAGE BY INTERVENTION OF SHEEP PLACENTA CREAM IN ELDERLY POPULATION AT STW CIBUBUR PERIOD SEPTEMBER 2019
}

\author{
Jessica Elizabeth ${ }^{1}$, Sukmawati Tansil Tan ${ }^{2}$, Yohanes Firmansyah ${ }^{3}$, Yana Sylvana ${ }^{4}$, \\ Michelle Angelika ${ }^{5}$
}

\author{
${ }^{1}$ Department of Dermatovenerology, Tarumanagara University, Jakarta \\ Email: je.chika19@gmail.com \\ ${ }^{2}$ Department of Dermatovenerology, Tarumanagara University, Jakarta \\ Email: sukmawati@fk.untar.ac.id \\ ${ }^{3}$ Department of Dermatovenerology, Tarumanagara University, Jakarta \\ *Email: yohanesfirmansyah28@gmail.com \\ ${ }^{4}$ Department of Dermatovenerology, Tarumanagara University, Jakarta \\ Email: sylvanayana@gmail.com
}

${ }^{5}$ Department of Dermatovenerology, Tarumanagara University, Jakarta

Email: michelleangelika111@gmail.com

Masuk: 29-02-2020, revisi: 17-08-2020, diterima untuk diterbitkan: 30-09-2020

\begin{abstract}
ABSTRAK
Population Reference Bureau (PRB) memperkirakan bahwa Indonesia akan mengalami lonjakan populasi menjadi 365,3 juta jiwa pada tahun 2030 yang selanjutnya akan berdampak terhadap lonjakan populasi lanjut usia serta peningkatan permasalahan kesehatan yang terjadi pada lansia. Salah satu permasalahan kesehatan lansia yang sering terjadi pada kulit adalah masalah hidrasi kulit. Ekstrak plasenta yang diproses dari hewan sudah banyak tersedia secara komersial dalam bentuk krim dengan tujuan memperbaiki komponen kulit. Meskipun efek ekstrak plasenta sebagian besar telah dipelajari, namun belum ada studi ilmiah yang melaporkan penggunaan ekstrak plasenta domba untuk meningkatkan kadar hidrasi kulit. Tujuan penelitian ini adalah untuk mencari peningkatan kadar hidrasi kulit lansia setelah penelitian intervensi berupa krim ekstrak plasenta domba. Penelitian ini merupakan penelitian quasi eksperimental, dengan metode pengambilan sampel berupa total sampling. Penelitian dilakukan di Panti STW RIA Pembangunan Cibubur pada periode September 2019. Krim plasenta domba dibuat dengan mencampur 30 gram bubuk ekstrak plasenta dengan 1000 gram basis krim. Kadar hidrasi kulit diukur menggunakan korneometer Skin Analyzer Runve HL-611. Responden lalu mengoleskan krim plasenta domba pada tangan kiri 15 menit setelah mandi. Pengukuran status hidrasi kulit diukur setiap 1 minggu hingga 4 kali pengukuran. Perubahan kadar hidrasi kulit lengan kiri dari 51 responden berturut-turut pada minggu ke nol hingga minggu ketiga adalah sebesar 35,10 \pm $2,81,35,96 \pm 2,57,36,28 \pm 2,31$, dan 36,88 $\pm 2,30$. Analisa uji statistik menggunakan uji Repeated Measurement didapatkan hasil kenaikan hidrasi yang bermakna (p-value $<0,001)$ antar pengukuran akibat pemberian intervensi berupa Krim Plasenta Domba. Peningkatan kadar hidrasi paling tinggi adalah antara pengukuran minggu ke nol dengan minggu ke tiga yaitu sebesar $1,784(0,276) \%$. Sebagai kesimpulan, pelembab dari ekstrak plasenta domba terbukti dapat peningkatkan kadar hidrasi kulit lansia setelah pemakaian selama 3 minggu ( $p$-value $<0,05$ ).
\end{abstract}

Kata Kunci: lansia; plasenta domba; status hidrasi

\begin{abstract}
The Population Reference Bureau (PRB) estimates that Indonesia will experience a population surge to 365.3 million by 2030, which will further affect the surge in the elderly population and increase health problems occurring in the elderly. One of the elderly health problems that often occur on the skin is skin hydration problem. Comercially available animal-derived placenta extracts are available in cream form for the purpose repairing skin components. Although the effects of placenta extract have been largely observed, no scientific studies have reported using sheep placenta extract to improve skin hydration levels. The purpose of this study was to look for an increase
\end{abstract}


in the hydration level of elderly skin after intervention research in the form of sheep placenta extract cream. This research is a quasi-experimental study, with a total sampling method in the form of sampling. The study was conducted at the STW RIA Pembangunan Cibubur in September 2019. Sheep placenta cream is made by mixing 30 grams of placenta extract powder with 1000 grams of cream base. Skin hydration levels were measured using the Skin Analyzer Runve HL-611 corneometer. Respondents then apply the cream on the left forearm within 15 minutes after bathing. Skin hydration levels are measured every 1 week up to 4 times measurement. Changes in skin hydration in 51 respondents in a row from week 0 to week 3 were $35.10 \pm 2.81,35.96 \pm 2.57,36.28 \pm 2.31$, and $36.88 \pm 2.30$. Analysis of statistical tests using the Repeated Measurement test showed a significant increase in hydration ( $p$-value <0.001) between measurements due to intervention. The highest increase in hydration level was between the measurement of week-to-zero with the third week of 1.784 (0.276)\%. As Conclusion, moisturizer from sheep placenta extract has been proven to increase the hydration level of elderly skin after using it for 3 weeks ( $p$ value $<0.05$ ).

Keywords: elderly; sheep placenta; skin hydration

\section{INTRODUCTION}

\section{Background}

The aging process is a natural process that occurs in all humans without exception. The aging process itself will cause changes in anatomy and physiology which of course have an impact on aspects of human life both social, economic, and health (Shai et al., 2009). Along with the increase in life expectancy, the number of elderly population in the world has increased significantly. The WHO census estimates the increase in the elderly population in the world by $10 \%$ to $22 \%$ or from 800 million people to 2 billion people. The elderly population in Asia and Southeast Asia are $7 \%$ and $6 \%$ of the total demographic (Population Reference Bureau, 2016a, 2016b, 2017, 2018). The Population Reference Bureau (PRB) estimates that Indonesia will get a population surge to 365.3 million by 2030 which will further affect the surge in the elderly population and increase health problems that occur in the elderly.(Jin et al., 2015) One of the elderly health problems that often occur on the skin is the problem of skin hydration.(Berger et al., 2013; Haroun, 2003; Hurlow \& Bliss, 2011; A. V. Rawlings \& Matts, 2007; ValdesRodriguez et al., 2015; White-Chu \& Reddy, 2011)

The skin is the largest human organ which has a weight of about $16 \%$ of the total body weight, the skin has various functions such as thermoregulation, barrier function (protection), metabolic and regulatory functions, and sensation functions. Along with increasing age, there will be a decrease in the function of the barrier (protection) from both the mechanical barrier, immunological barrier, and biochemical barrier.(Grover \& Grewal, 2008; Payne \& Stanley, 2012) The mechanical barrier component that maintains skin hydration is the statum corneum. Skin hydration and moisture in the stratum corneum are endogenously regulated by natural moisturizing factor (NMF), skin lipid interactions, and water channel proteins, especially the aquaporin-3 (AQP-3) component. Aquaporin-3 (AQP-3) is responsible for water and glycerone transport which functions as a natural humectant.(A. V. Rawlings \& Harding, 2004; Robinson et al., 2010) As we get older, the expression of AQP-3 and the amount of lipids in the stratum corneum will decrease so that it will cause a decrease in skin hydration. Apart from age, the hydration status of the skin itself can also be determined by the use of soap, shower frequency, systemic disease, mechanical trauma, the use of moisturizers on a regular basis and many other factors. (Cao et al., 2008)

The placenta is a fetomaternal organ, which means it becomes a link between the fetus and the mother or mother. In general, the placenta functions as a means of exchanging nutrients and gas, between the fetus and the mother, and produces hormones. Anatomically, the human placenta is flat, discoid and has a layer of tissue that separates maternal and fetal blood vessels. The placenta 
functions as an organ that facilitates the exchange of gases and nutrients, such as glucose, amino acids, fatty acids, vitamins, minerals and various other nutrients that are useful for intrauterine fetal development. Various kinds of constituents contained in the placenta, including nucleic acids, amino acids and proteins, vitamins and minerals, components of extracellular matrix, cytokines and growth factors that are good for the skin .(Cao et al., 2008) There is a study about effect of porcine placental extract at concentration of $12.5-100 \mu \mathrm{g} / \mathrm{m}$ could promote collagen production in Normal Human Dermal Fibroblasts (NHDFs) by enhancing their secretion and proliferation of pro-collagen $\mathrm{C}$ peptide. (Yoshikawa, et al., 2013)

In Indonesia, there are no studies that analyze the relationship between the use of moisturizers from sheep placental extracts to the hydration levels of the elderly skin. The management of dry skin in the elderly group has not yet received special attention in Indonesia. Sasana Tresna Werdha Karya Bhakti Ria Cibubur Pembangunan currently accommodates an age group that is generally $\geq 60$ years with demographic characteristics that adequately represent the population group $\geq 60$ years both in terms of age, religion, gender, race and ethnicity, past occupation, and culture. Researchers are interested in examining changes in skin hydration levels in the age group $\geq 60$ years with the intervention of sheep placenta extract cream.

\section{METHOD}

This research is a clinical trial research with quasi-experimental design carried out at the Nursing Home of STW Karya Bhakti Ria Pembangunan Cibubur in the September 2019. The sample of this research is all elderly groups who are in the sampling place of Nursing Homes of STW Karya Bhakti Ria Pembangunan Cibubur in the September 2019 and meet the inclusion criteria. The estimated sample size in this study is 50 respondents with a total sampling method in the form of sampling. The inclusion criteria in this study were respondents aged $\geq 60$ years, willing to stop using drugs and other skin care such as hand or body lotion that had been used for at least 3 days, and the estimated length of life until the study was completed. Exclusion criteria in this study were respondents who refused to participate in the study, respondents with skin disorders, who were associated with infectious diseases, irritants, and suspicious respondents with a history of allergies to drug composition, or respondents with major mental disorders and severe psychotic conditions. Sheep placenta cream is made by mixing 30 grams of placenta extract powder with 1000 grams of cream base. Skin hydration levels were measured using the Skin Analyzer Runve HL-611 corneometer. The independent variable in this study was the use of sheep placenta extract cream which was applied to the left forearm within 15 minutes after bathing, and the dependent variable in this study was the skin hydration percentage of the left forearm skin at weeks $0,1,2$, and 3. Statistical analysis using statistical Repeated Measurement tests to measure the significance between measurements simultaneously. This research has obtained ethical review permission from Universitas Tarumanagara Human Research Ethic Community (UTHREC).

\section{RESULTS AND DISCUSSION}

The results of the study about improvement of skin hydration with sheep placenta cream intervention, obtained a total of 52 respondents (the number of respondents should be 53 respondents or 126 application locations), where $17(32.7 \%)$ respondents were male and 35 $(67.3 \%)$ respondents are women. Racial distribution is dominated by Javanese $23(44.2 \%)$ and religion is dominated by Islam 49 (94.2\%) respondents. 
Table 1. Distribution of Characteristics of 52 Respondents in the Nursing Home of STW Ria Pembangunan Cibubur

\begin{tabular}{lccc}
\hline \multicolumn{1}{c}{ Variable } & $\begin{array}{c}\text { Total }(\%) \\
\mathbf{N}=\mathbf{5 2}\end{array}$ & Mean \pm SD & $\begin{array}{c}\text { Median } \\
\text { (Min ; Max })\end{array}$ \\
\hline Gender & $17(32,7 \%)$ & - & - \\
Male & $35(67,3 \%)$ & - & - \\
Female & - & $79,35 \pm 8,572$ & $79(61 ; 99)$ \\
Age & $23(44,2)$ & - & - \\
Races: & $4(7,7)$ & - & - \\
Javanese ethnic & - & - & - \\
Sundanese tribe & $3(5,8)$ & - & - \\
Chinese-Indonesian tribe & - & - & \\
Malay tribe & $4(7,7)$ & & \\
Madurese & $3(5,8)$ & & \\
Batak tribe & $6(11,5)$ & & \\
Minangkabau tribe & - & & \\
Betawi culture & - & & \\
Arab tribes - Indonesia & $1(1,9)$ & & \\
Banjar tribe & - & & \\
Banten tribe & - & & \\
Balinese tribe & $1(1,9)$ & & \\
Makassar tribe & $7(13,5)$ & & \\
Cirebon tribe & & & \\
Others & $49(94,2)$ & & \\
Religions: & $3(5,8)$ & & \\
Islam & & & \\
Christian & & & \\
\hline
\end{tabular}

Research on improving skin hydration with sheep placenta cream intervention obtained a total of 52 respondents from 63 respondents. The difference between respondents or 11 other respondents was excluded because they refused, were not routinely in the institution every week, and were not in the institution in the first week and the second week of the intervention. A total of 52 respondents ran for 14 days and 1 respondent dropped out or refused to continue on day 14 . The study ended with the number of respondents who successfully completed the study of 51 respondents.

The mean hydration of the skin of the left arm of 52 respondents at zero week was $35.06 \pm$ $2.789 \%$. The left arm was then intervened with sheep placenta cream and measured skin hydration in the first week at $35.935 \pm 2.544 \%$, and the second week at $36.244 \pm 2.306 \%$. The mean hydration of the skin of the left arm 51 respondents at the end of the study or in the third week with hydration of $36.880 \pm 2.306 \%$. Skin hydration status at the beginning of the study was dominated by dry skin by $25(48.1 \%)$ respondents and very dry skin by $19(36.5 \%)$ respondents. Skin hydration status was measured every week after administration of sheep placenta cream intervention and the results obtained in the first week of hydration status of dry and normal skin were $29(55.8 \%)$ respondents and $12(23.1 \%)$ respondents, results in the second week hydration status of dry and normal skin respectively as many as $30(57.7 \%)$ respondents and $14(26.9 \%)$ respondents, results in the third week (end of the study) hydration status of dry and normal skin respectively were $24(46,2 \%)$ respondents and $20(38.5 \%)$ respondents

Table 2 Characteristics Distribution of the Left Arm Skin Hydration Status of 52 Respondents in the Nursing Home of STW Ria Pembangunan Cibubur 


\begin{tabular}{|c|c|c|c|}
\hline Variable & $\begin{array}{c}\text { Total }(\%) \\
\mathrm{N}=52\end{array}$ & Mean \pm SD & Median (Min ; Max) \\
\hline Hydration at Zero Week (N : 52) & - & $35,06 \pm 2,789$ & $35,40(26,6 ; 41,2)$ \\
\hline \multicolumn{4}{|l|}{ Skin Hydration Status at Week-0 } \\
\hline$(\mathbf{N}: 52)$ & & - & - \\
\hline Very dry skin & $19(36,5 \%)$ & - & - \\
\hline Dry skin & $25(48,1 \%)$ & & \\
\hline Normal & $8(15,4 \%)$ & & \\
\hline Moist & - & & \\
\hline Vert Moist & - & & \\
\hline Skin Hydration at Week 1 (N : 52) & - & $35,935 \pm 2,544$ & $36,10(29,4 ; 41,5)$ \\
\hline \multicolumn{4}{|l|}{ Skin Hydration Status at Week-1 } \\
\hline$(N: 52)$ & & - & - \\
\hline Very dry skin & $11(21,2 \%)$ & - & - \\
\hline Dry skin & $29(55,8 \%)$ & & \\
\hline Normal & $12(23,1 \%)$ & & \\
\hline Moist & - & & \\
\hline Vert Moist & - & & \\
\hline Skin Hydration at Week 2 (N : 52) & - & $36,244 \pm 2,306$ & $36,70(30,5 ; 39,8)$ \\
\hline \multicolumn{4}{|l|}{ Skin Hydration Status at Week-2 } \\
\hline$(\mathrm{N}: 52)$ & & - & - \\
\hline Very dry skin & $8(15,4 \%)$ & - & - \\
\hline Dry skin & $30(57,7 \%)$ & & \\
\hline Normal & $14(26,9 \%)$ & & \\
\hline Moist & - & & \\
\hline Vert Moist & - & & \\
\hline Skin Hydration at Week 3 (N : 51) & - & $36,880 \pm 2,306$ & $37,40(31,5 ; 40,7)$ \\
\hline \multicolumn{4}{|l|}{ Skin Hydration Status at Week-3 } \\
\hline$(\mathbf{N}: \mathbf{5 1})$ & & - & - \\
\hline Very dry skin & $7(13,5 \%)$ & - & - \\
\hline Dry skin & $24(46,2 \%)$ & & \\
\hline Normal & $20(38,5 \%)$ & & \\
\hline Moist & - & & \\
\hline Vert Moist & - & & \\
\hline
\end{tabular}

Improvement in skin hydration percentages of the left arm from 51 respondents in a row from week 0 to week 3 were $35.10 \pm 2.81 \%, 35.96 \pm 2.57 \%, 36.28 \pm 2.31 \%$, and $36.88 \pm 2.30 \%$. The normality test results using the Kolmogorov-Smirnov test obtained p-value>0.05 which indicates that all hydration percentages have a normal distribution of data every week. Analysis of statistical tests using the Repeated Measurement test showed a significant increase in hydration (p-value <0.001) between measurements due to intervention in the form of Sheep Placenta Cream. The highest increase in hydration level was between the measurement of zero week and the third week of $1.784(0.276) \%$. 
Table 3 Comparison of Left Arm Skin Hydration Percentages with Sheep Placenta Cream Interventions from Week 0 to Week 3

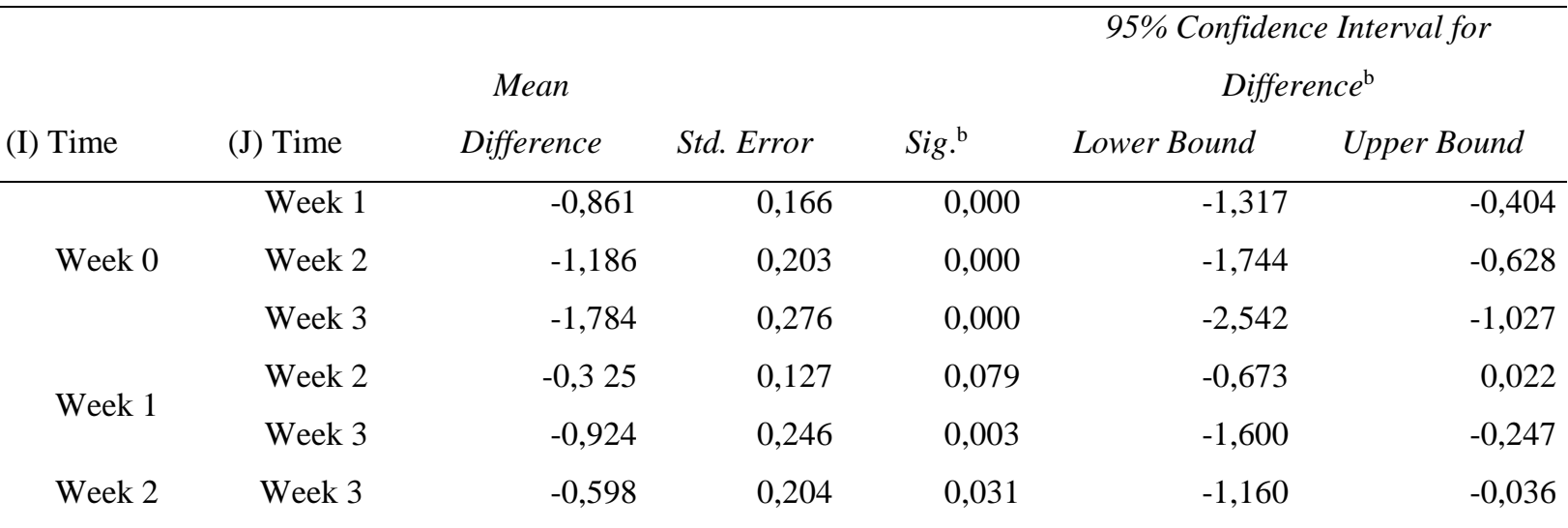

Based on estimated marginal means

*. The mean difference is significant at the .05 level.

b. Adjustment for multiple comparisons: Bonferroni.

Mean Hydration Week $0: 35,10 \pm 2,81$

Mean Hydration Week $2: 36,28 \pm 2,31$

Mean Hydration Week $1: 35,96 \pm 2,57$

Mean Hydration Week $3: 36,88 \pm 2,30$

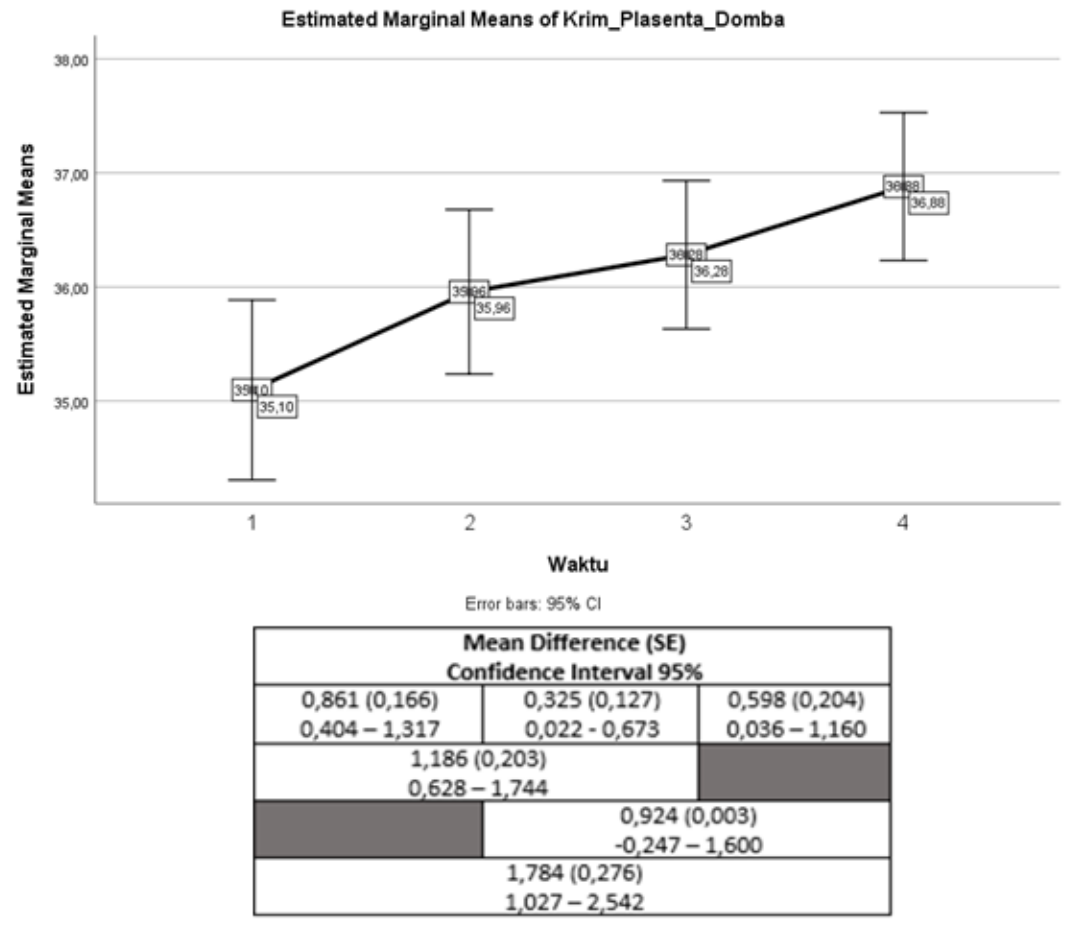

Graph 1 Comparison of Left-Armed Skin Hydration Levels with Sheep Placenta Cream Interventions from Week 0 to Week 3

The use of moisturizers on a regular basis can inhibit TEWL through an occlusion mechanism. Hydration of cells in the stratum corneum originates from the inner layer of the epidermis which moves upward. Occlusive moisturizers have a duty to prevent dehydration that occurs in the stratum corneum. The loss of intracellular lipids, for example cholesterol, ceramids, and free fatty acids that make up the bilayer will cause the water barrier function to be damaged. The 
stages of the moisturizing process include: improving the skin barrier function, increasing the skin's water content, reducing the TEWL number, increasing the ability of the lipid barrier to extract, hold, and redistribute water.(Lynde, 2001)

The placenta functions as an organ that facilitates the exchange of gases and nutrients, such as glucose, amino acids, fatty acids, vitamins, minerals and various other nutrients that are useful for intrauterine fetal development. Various kinds of constituents contained in the placenta, including: (Chakraborty \& Bhattacharyya, 2005; De et al., 2011; S. \& D., 2007; Singh \& Bhattacharyya, 2017)

\section{Nucleic Acids}

The nucleic acids contained in the placenta are divided into two types, namely ribonucleic acid (RNA), deoxyribonucleic acid (DNA). In addition, there are active components of polydeoxyribonucleotide derived from polymer extracts that function to activate the biosynthetic pathway for nucleoside, nucleotide, and nucleic acids. Clinically, the component of PRDN has the ability to heal wounds that are often used for the treatment of ulcers, wounds, or scarring.(Lobo et al., 2016)

\section{Amino Acids and Proteins}

Amino acids and proteins function as building blocks in the placenta. Various essential and nonessential amino acids are found in the placenta, including alanine, aspartate acid, arginine, histidine, leucine, lysine, phenylalanine, proline, tyrosine, tritofan, and valine. Clinically, the amino acids found in placental therapy function to stimulate fibroblast and collagen production and reduce skin hyperpigmentation.(Chakraborty \& Bhattacharyya, 2005; De et al., 2011; S. \& D., 2007; Singh \& Bhattacharyya, 2017)

\section{Vitamin \& Mineral}

Metabolic processes and the formation of intrauterine organs, vitamins and minerals are needed to maintain the stability of the process. In the placenta, there are specific vitamin $\mathrm{B}$ attachment sites, especially for vitamins B1, B2, B5, B6, B7, B9, B12. These vitamins have a important role in metabolism, division, and cell development and energy production. The minerals found in the placenta function to maintain normal development and bodily functions. Minerals contained in the placenta include calcium, copper, iron, magnesium, manganese, phosphorus, potassium silicon, sodium, and zinc. (Chakraborty \& Bhattacharyya, 2005; De et al., 2011; S. \& D., 2007; Singh \& Bhattacharyya, 2017)

\section{Extracellular Matrix Components}

The dermal layer on the skin is largely composed of extracellular matrix components that support inter-cell integrity. Extracellular matrix functions to maintain surface tension, cell adhesion regulation, and tissue development. The extracellular matrix component consists of collagen, proteoglycans / glycosaminoglycans, elastin, fibronectin, laminin, and glycoprotein. The placenta has an extracellular matrix component that is rich in elastin making it possible to retain structural integrity despite experiencing strong stress. (Lee et al., 2016)

Placental cells have intracellular communication systems that aim to stimulate cellular responses with receptors on the cell surface. The intracellular communication system is mediated by cytokines through autocrine, paracrine and endocrine signals. Cytokines present in the placenta include interleukin-1 (IL-1) which function to regulate the immune system, especially the production of T, B, and NK cells; interleukin-2 (IL-2) which functions for regulation of T cell 
activity and growth, as well as immune regulators or mediators; interleukin-4 (IL-4) which functions for the elimination of extracellular pathogens and regulation of antibody production, as well as the differentiation of T-helper 0 (Th0) cells into T-helper 1 (Th1) and T-helper 2 (Th2). (Chakraborty \& Bhattacharyya, 2005; De et al., 2011; S. \& D., 2007; Singh \& Bhattacharyya, 2017)

Growth factor is an important factor in the regulation and stimulation of growth, proliferation, migration and cell differentiation. Growth factors contained in the placenta, including granulocyte-colony stimulating factor (G-CSF) and granulocyre-macrophage colony stimulating factor (GM-CSF) function as growth stimulators, differentiation and cell proliferation of each neutrophil and macrophages; Epidermal growth factors (EGF) that function epidermal migration and proliferation for wound healing; Fibroblast growth factor (FGF) functions to stimulate fibroblast growth and endothelial migration in wound healing.(Chakraborty \& Bhattacharyya, 2005; De et al., 2011; S. \& D., 2007; Singh \& Bhattacharyya, 2017)

Currently there are several studies on the effectiveness of topical and oral animal derived placenta extract against skin components, most of then use porcine placenta extract, but there are no studies using sheep placenta extract. An experimental study of anti-inflammatory and antioxidative effects of topical porcine placenta extract against contact dermatitis results in reduction of local and systemic symptoms. Epidermal thickening and allergen specific serum IgE were significantly reduced. (Heo, et al., 2018) Porcine placenta shows to have anti aging effects, whitening, and anti-wrinkle effects which are useful for treating skin condition that occurs in elderly. (Young, et al., 2010) A randomized controlled trial to compare the effects of topical placenta extract cream and gel in treatment of chronic wound shows that placental extract gel and cream have similar scores in Microscopic Angiogenesis Grading System (MAGS). However, less pain and discomfort during dressing change were recorded in placenta extract cream group. (Tiwary, et al., 2013)

The advantage of cream based skin treatment is that it is able to increase the concentration gradient of the active substance that penetrates the skin. Based on the results of previous studies, we chose cream as a base material for sheep placenta extract. Another consideration is that placenta extract have a polar or neutral nature, so that cream based placenta extract will be easier to wash of with water and doesn't cause stickiness on the skin surface and improve patient comfort.

\section{CONCLUSSION AND SUGGESTION}

There is an increase in skin hydration levels in the elderly after routine use of sheep placenta extract cream for 3 weeks ( $p$-value <0.05). Encourage continuous (routine) use of sheep placenta extract cream for at least 3 weeks in order to improve hydration levels

\section{Acknowledgement}

Our gratitude goes to Tarumanagara University's Human Research Ethics Committee as a research ethics committee, PT. Sukma Skin Treatment as financier and Panti STW RIA Pembangunan Cibubur as facilitator. 


\section{REFERENCE}

Berger, T. G., Shive, M., \& Harper, G. M. (2013). Pruritus in the older patient: A clinical review. In JAMA - Journal of the American Medical Association. https://doi.org/10.1001/jama.2013.282023

Cao, C., Wan, S., Jiang, Q., Amaral, A., Lu, S., Hu, G., Bi, Z., Kouttab, N., Chu, W., \& Wan, Y. (2008). All-trans retinoic acid attenuates ultraviolet radiation-induced down-regulation of aquaporin-3 and water permeability in human keratinocytes. Journal of Cellular Physiology. https://doi.org/10.1002/jcp.21336

Chakraborty, P. D., \& Bhattacharyya, D. (2005). Isolation of fibronectin type III like peptide from human placental extract used as wound healer. Journal of Chromatography B: Analytical Technologies in the Biomedical and Life Sciences. https://doi.org/10.1016/j.jchromb.2004.09.059

De, D., Chakraborty, P. D., \& Bhattacharyya, D. (2011). Regulation of trypsin activity by peptide fraction of an aqueous extract of human placenta used as wound healer. Journal of Cellular Physiology. https://doi.org/10.1002/jcp.22535

Grover, S., \& Grewal, R. (2008). Fitzpatrick's Dermatology in General Medicine. Medical Journal Armed Forces India. https://doi.org/10.1016/s0377-1237(08)80108-6

Haroun, M. T. (2003). Dry skin in the elderly. Geriatrics and Aging.

Heo, J. et al., 2018. Topical anti-inflammatory and anti-oxidative effects of porcine placenta extracts on 2,4-dinitrochlorobenzene-induced contact dermatitis. BMC Complementary and Alternative Medicine, Volume 18.

Hurlow, J., \& Bliss, D. Z. (2011). Dry Skin in Older Adults. Geriatric Nursing. https://doi.org/10.1016/j.gerinurse.2011.03.003

Jin, K., Simpkins, J. W., Ji, X., Leis, M., \& Stambler, I. (2015). The critical need to promote research of aging and aging-related diseases to improve health and longevity of the elderly population. In Aging and Disease. https://doi.org/10.14336/AD.2014.1210

Lee, H. Y., Chae, H. J., Park, S. Y., \& Kim, J. H. (2016). Porcine placenta hydrolysates enhance osteoblast differentiation through their antioxidant activity and effects on ER stress. BMC Complementary and Alternative Medicine. https://doi.org/10.1186/s12906-016-1274-y

Lobo, S. E., Leonel, L. C. P. C., Miranda, C. M. F. C., Coelho, T. M., Ferreira, G. A. S., Mess, A., Abrão, M. S., \& Miglino, M. A. (2016). The placenta as an organ and a source of stem cells and extracellular matrix: A review. In Cells Tissues Organs. https://doi.org/10.1159/000443636

Lynde, C. W. (2001). Moisturizers: what they are and how they work. In Skin therapy letter.

Payne, A. S., \& Stanley, J. (2012). Fitzpatrick's Dermatology. In Mc-Grawhill education.

Population Reference Bureau. (2016a). 2016 World Population Data Sheet. 2015 World Population Data Sheet. https://doi.org/10.2307/1972177

Population Reference Bureau. (2016b). 2016 World Population Data Sheet with a Special Focus on Human Needs and Sustainable Resources. 2015 World Population Data Sheet. https://doi.org/10.2307/1972177

Population Reference Bureau. (2017). World Population Data Sheet WITH A SPECIAL FOCUS ON YOUTH. World Population Data Sheet.

Population Reference Bureau. (2018). World Population Data Sheet 2018 With Special Focus on Changing Age Structures. Worldpopdata.Org.

Rawlings, A. V., \& Matts, P. J. (2007). Dry skin and moisturizers. In Dermatologic, 
Cosmeceutic, and Cosmetic Development: Therapeutic and Novel Approaches. https://doi.org/10.3109/9780849375903-22

Rawlings, A. V., \& Harding, C. R. (2004). Moisturization and skin barrier function. Dermatologic Therapy. https://doi.org/10.1111/j.1396-0296.2004.04s1005.x

Robinson, M., Visscher, M., Laruffa, A., \& Wickett, R. (2010). Natural moisturizing factors (NMF) in the stratum corneum (SC). I. Effects of lipid extraction and soaking. Journal of Cosmetic Science. https://doi.org/10.1111/j.1468-2494.2010.00591_2.x

S., N., \& D., B. (2007). Cell adhesion by aqueous extract of human placenta used as wound healer. Indian Journal of Experimental Biology.

Shai, A., Maibach, H., \& Baran, R. (2009). Handbook of Cosmetic Skin Care (2nd Edition). In Handbook of Cosmetic Skin Care (2nd Edition). https://doi.org/10.3109/9781616310004

Singh, N., \& Bhattacharyya, D. (2017). Biochemical and functional analysis of corticotropin releasing factor purified from an aqueous extract of human placenta used as wound healer. Journal of Pharmaceutical and Biomedical Analysis. https://doi.org/10.1016/j.jpba.2017.06.060

Tiwary, S. et al., 2013. Effect of placental-extract gel and cream on non-healing wounds. Journal of Wound Care, 15(7).

Valdes-Rodriguez, R., Stull, C., \& Yosipovitch, G. (2015). Chronic Pruritus in the Elderly: Pathophysiology, Diagnosis and Management. In Drugs and Aging. https://doi.org/10.1007/s40266-015-0246-0

White-Chu, E. F., \& Reddy, M. (2011). Dry skin in the elderly: Complexities of a common problem. Clinics in Dermatology. https://doi.org/10.1016/j.clindermatol.2010.07.005

Yoshikawa, C. et al., (2013). Effect of Porcine Placental Extract on Collagen Production in Human Skin Fibroblasts In Vitro. Gynecol Obstet, 3(6).

Young, K. et al., (2010). Functional Cosmetic Effect of Porcine Placeta. Korean Chemical Engineering Research, 48(3). 